\title{
Histopathological evaluation and expression profile of PRM-1, TNP-2, 17B-HSD3, LHR, MHC-I, MIC-B, NCl and NC3 genes in bovine testis
}

\section{Análise histopatológica e perfil de expressão dos genes PRM-I, TNP-2, 17B-HSD3, LHR, MHC-I, MIC-B, NCI e NC3 em testículo bovino}

\author{
Daniele Rosa Xavier ${ }^{1}$ (D), Auricelio Alves de Macedo ${ }^{2}$ (D), Larissa Sarmento dos Santos ${ }^{3}$ (1), \\ Taynan Dulce da Silva Rosa ${ }^{4}$ (1), Ellainy Maria Conceição Silva 5 (1), Fábio Henrique Evangelista de Andrade ${ }^{6}$ (D), \\ José Ribamar de Souza Torres-Júnior ${ }^{7}$ (1), Alcina Vieira de Carvalho-Neta ${ }^{8 *}$ (1)
}

\begin{abstract}
Histopathological and spermatogenesis classification by Johnsen is widely used in the germinal epithelium maturation analysis, besides identifying pathological alterations able to cause subfertility and even infertility. The aim of this study was to analyze cell-differentiation histopathological data and to correlate them with expression of PRM-1, TNP-2, 17 $3-$ HSD3, LHR, generic MHC-I, MIC-B, NC1 and NC3 genes, involved in bovine spermatogenesis using qRT-PCR from testicular parenchyma. Based on Johnsen's criteria, the results showed normal spermatogenic activity in these animals, classified at 6, 7 and 8 scores. The qRT-PCR analysis expression showed that MHC-I (generic) gene was less expressed than all the other genes in evaluated scores $(\mathrm{p}<0.05)$ and, PRM-1 and TNP-2 were the most expressed genes $(\mathrm{p}<0.05)$. The PRM-1 gene expression was significantly higher than TNP-2 $(\mathrm{p}<0.05)$. Comparing scores, $17 \beta-$ HSD3 gene expression was lower $(\mathrm{p}<0.05)$ in score 6 when compared to scores 7 and 8 animals. It was also observed that PRM-1 expression was lower in score 6 when compared to 7, as well as TNP-2 gene was less expressed in the score $6(\mathrm{p}<0.05)$ when compared to 7 and 8 scores. Our results demonstrated that MHC I (generic), MIC-B, NC1, NC3, and LHR genes are poorly expressed in bovine testis, suggesting their marginal action on spermatogenesis. Instead, PRM-1, TNP-2, and 17 $\beta$-HSD3 expression were higher, supporting the notion that these genes can act directly on the germ cells differential development during bovine spermatogenesis.
\end{abstract}

KEYWORDS: cattle, male bovine, spermatogenesis, gene expression, testis

RESUMO: A classificação histopatológica e espermatogênica segundo Johnsen é amplamente utilizada na análise da maturação do epitélio germinativo, além de identificar alterações patológicas capazes de causar subfertilidade e até infertilidade. O objetivo deste estudo foi analisar dados histopatológicos de diferenciaçáo celular e correlacioná-los à expressão dos genes PRM-1, TNP-2, 17ß-HSD3, LHR, MHC-I genérico, MIC-B, NC1 e NC3, envolvidos na espermatogênese bovina usando qRT-PCR do parênquima testicular. Com base nos critérios de Johnsen, os resultados demonstraram atividade espermatogênica normal nesses animais, classificados nos escores 6, 7 e 8. A análise de expressão gênica (qRT-PCR) demonstrou que o gene MHC-I (genérico) foi menos expresso do que os demais nos escores avaliados ( $p<0,05)$ e, PRM-1 e TNP-2 foram os mais expressos $(\mathrm{p}<0,05)$. A expressão do PRM-1 foi significativamente maior do que TNP-2 $(\mathrm{p}<0,05)$. Comparando os escores, a expressão do $17 \beta$-HSD3 foi menor $(p<0,05)$ no escore 6 quando comparado aos escores 7 e 8 . Observou-se também que a expressão do PRM-1 foi menor no escore 6 quando comparado ao 7, bem como o TNP-2 foi menos expresso no escore 6 (p < $0,05)$ quando comparado aos escores 7 e 8 . Nossos resultados demonstraram que os genes MHC-I (genérico), MIC-B, NC1, NC3 e LHR são pouco expressos em testículos bovinos, sugerindo sua ação indireta na espermatogênese. Em contrapartida, a expressão de PRM-1, TNP-2 e 17ß-HSD3 foi alta, corroborando com a hipótese de que esses genes podem atuar diretamente no desenvolvimento diferencial de células germinativas durante a espermatogênese bovina.

PALAVRAS-CHAVE: gado, bovino macho, espermatogênese, expressão gênica, testículo

\footnotetext{
1 Post-Graduate Program in Animal Science, Universidade Estadual do Maranhão.

${ }^{2}$ Veterinary Medicine course, Faculdade Vale do Aço - FAVALE, Açailandia/MA.

${ }^{3}$ Pathology Department, Universidade Estadual do Maranhão.

${ }^{4}$ Molecular Pathology Lab, Universidade Estadual do Maranhão.

${ }^{5}$ Post-Graduate Program in Animal Science, Universidade Estadual do Maranhão.

6 Pathology Department, Universidade Estadual do Maranhão.

7 Department of Oceanography and Limnology, Universidade Federal do Maranhão.

${ }^{8}$ Chemistry and Biology Department, Universidade Estadual do Maranhão.

*Corresponding author: alcinavcn@yahoo.com

Received: 06/24/2020. Accepted: 11/07/2020
} 


\section{INTRODUCTION}

Spermatogenesis is characterized by a series of mitotic and meiotic divisions and a complex morphological, physiologi$\mathrm{cal}$, and biochemical modifications occurring in the testis to form sperm (JOHNSON et al., 2000). The inadequate germ cells differential development (spermatogonia, spermatocytes, and spermatids), besides Sertoli and Leydig cells, can affect the reproductive capacity and lead to subfertility or even to infertility (ARRUDA et al., 2015). The cellular differentiation degree is regulated by neuroendocrine factors, including the Luteinizing Hormone (LH), 17 $\beta$-Hydroxysteroid Dehydrogenase type 3 (17 $\beta$-HSD3) (which participates in androstenedione conversion into testosterone), Transition Nuclear Proteins (TNPs) types 1 and 2, and Protamines (PRMs) (GRISWOLD, 1995; MEISTRICH et al., 2003; FERRAZ et al., 2013).

Other molecules probably involved in spermatogenesis are those from the Major Histocompatibility Complex (MHC), which encode two main cell-surface glycoprotein types $M H C$ classes $I$ and $I I$ molecules. These molecules are associated with innate and adaptive immune responses responsible for processing and presenting foreign antigens to $\mathrm{CD}^{+}$and $\mathrm{CD4}^{+} \mathrm{T}$ cells, respectively (TROWSDALE, 2001; KELLEY; WALTER; TROWSDALE, 2005).

The MHC class I molecules can be divided into classical (MHC-Ia) and non-classical (MHC-Ib) (DAVIES, 2007). Furthermore, MHC-Ib molecules are much less polymorphic, have restricted cellular expression, and interact with inhibitory receptors such as NKG2, which belongs to the Natural Killer - NK family (SHIROISHI et al., 2003; PARHAM, 2005; DAVIES et al., 2006). So far, the expression of MHC-Ib in bovine testis has not been the target of extensive studies; however, it plays a significant role in fertility regulation. It has been described in spermatozoa, prostate, testicular tissues, and seminal plasma from men and Rhesus Macaque (CHIANG et al., 1994; RYAN et al., 2002; LANGAT et al., 2006; LARSEN et al., 2011; YAO et al., 2014).

The histopathological analysis of testis is essential to better understand the process leading to spermatogenesis and the correlation between physiological and biochemical functions, and pathological changes (MCLACHLAN et al., 2007). Thus, the aim of the present research was to analyze cell-differentiation histopathological data through Johnsen's criteria and the PRM-1, TNP-2, 17 $\beta$-HSD3, LHR, MHCI, MIC-B, NC1, and NC3 genes expression profile involved in bovine spermatogenesis.

\section{MATERIALAND METHODS}

\section{Samples}

Testes fragments from 36 sexually mature male Nelore bovines (Bos taurus indicus) and crossbred bulls ( 3 to 5 years old) were obtained immediately after slaughter in commercial slaughterhouse located in Sáo Luís, Maranhão State, Brazil. All animals were considered clinically healthy prior to slaughter. The macroscopic appearance (parameters such as size, consistency, and color) of each testicular tissue was assessed right after the slaughtering. Tissue samples were placed in a $10 \%$ neutral buffered formaldehyde for 24 hours and processed by paraffin-embedding to histopathological spermatogenesis classification or in RNAse free sterile cryovials containing RNAlater reagent (Life Technologies, CA, USA), stored at $4-8^{\circ} \mathrm{C}$ for 24 hours, and further stored at $-20^{\circ} \mathrm{C}$ until RNA extraction for molecular analyses. All the experimental procedures were approved by the Ethics Committee on Animal Experimentation (Protocol 27/2016).

\section{Histopathological analyses}

Paraffin-embedded blocks were sectioned $(5 \mu \mathrm{m})$ in rotary microtome and stained with hematoxylin and eosin (HE). Stained sections were studied under light microscope to evaluate the tissues histological characteristics and categorize the spermatogenesis through Johnsen's criteria. The seminiferous tubules were classified according to the germinating epithelium maturation level considering the most advanced cell group in the tubule (spermatogonia, spermatocytes, round, and/or elongated spermatids). All tubular section were scored from 10 to 1 according to the main cell types arranged presence or absence ordered by maturity. Presence of spermatozoa scored 10, 9 or 8; spermatids (and no further) scored 7 or 6; spermatocytes (and no further) 5 or 4; only spermatogonia 3, only Sertoli cells 2 , and no cells 1 .

Each testis from the 36 animals was used in the experiment, thus totalizing 72 histological slides with testicular parenchyma, and 40 seminiferous tubule segments from each bull were randomly selected and scored according to Johnsen that was multiplied by its frequency to calculate the mean score after morphological identification; the sum was divided by the scored tubules total number.

Bovine testes were evaluated and categorized according to Johnsen (1970) and McLachlan et al. (2007) by defining the spermatogenesis classification as normal testicular biopsy, hypospermatogenesis, as well as diffuse tubular atrophy with tubular hyalinization, maturation arrest or Sertoli cell-only (SCO) syndrome based on the most advanced spermatogenesis pattern in histological examinations. Testicular structures were assessed according to the tubular and interstitial organization level, sperm morphology (uniformity or heterogeneity), seminiferous tubules diameter, with and without fibrosis; and Sertoli and Leydig cell development. Furthermore, the spermatogenesis evaluation of morphology classification purposes were adapted from the research on male infertility diagnosis by Turek (2005). 


\section{Molecular analyses}

After the mean scores classification by the quantitative histopathological analysis, 12 fragments from each score were selected to gene expression profile and descriptive studies.

Total RNA was extracted using Trizol (Invitrogen, CA, USA) according to the manufacturer recommendations. The RNA purity and concentration were assessed through spectrophotometry, and RNA quality was evaluated through agarose/formaldehyde gel electrophoresis. The cDNA synthesis was performed using $1.5 \mu \mathrm{g}$ of total RNA and the commercial kit Super Script III First-Strand Synthesis System (Invitrogen, CA, USA) - at $20 \mu \mathrm{L}$ per reaction final volume, according to the manufacturer recommendations.

Quantitative real time RT-PCR (qRT - PCR) was performed using $1 \mu \mathrm{L}$ of cDNA, $0.5 \mu \mathrm{L}$ of specific primers at $10 \mu \mathrm{M}$, and $5 \mu \mathrm{L}$ of PowerUp ${ }^{\mathrm{TM}} \mathrm{SYBR}^{\circledR}$ Green Master Mix - at $10 \mu \mathrm{L}$ per reaction final volume. The qPCR parameters were $50^{\circ} \mathrm{C}$ for two minutes, $95^{\circ} \mathrm{C}$ for two minutes, 40 cycles of $95^{\circ} \mathrm{C}$ for 15 seconds and $60^{\circ} \mathrm{C}$ for one minute in the StepOnePlus Real-time PCR System (Applied Biosystems, $\mathrm{CA}, \mathrm{USA})$. The qPCR was performed using a generic MHC class I primer pair named Bov 7 and 11 (BIRCH et al., 2006) which amplifies sequences of classical MHC-I and of non-classical MHC-I locus NC1. Primer pairs were used to amplify the non-classical MHC-I loci (MIC-B, NC1 and NC3) (SHU et al., 2012), PRM-1, and TNP-2 (FERRAZ et al., 2013) sequences. The specific primers used for $17 \beta$ HSD3 and LHR were delineated in the Primer 3 software (Table 1). The Cq values were normalized according to the GAPDH gene, since the GAPDH's Cq values were more stable than $\beta$-actin in our experiments, and analyzed through the comparative Cq method $\left(2^{-\Delta \Delta C t}\right)$ described by Livak and Schmittgen (2001).

\section{Statistical analysis}

Mann-Whitney's nonparametric test was used to compare the mean value scores. Normalized $\mathrm{Cq}$ values underwent logarithmic transformation prior to the variance analysis (ANOVA), and means were compared through Student's $\mathrm{t}$ test. Spearman's nonparametric correlation test was used to assess all the correlations between histopathological findings (mean Johnsen's score) and the gene expression in bovine testis. All statistical analysis was performed in GraphPad Prism 5.0 software (GraphPad Software, Inc., San Diego, CA, USA), and statistical significance was set when $\mathrm{p}<0.05$.

Table 1. Genes and primers used for qRT-PCR in this study.

\begin{tabular}{|c|c|c|c|c|}
\hline Genes* & Primers $\left(5^{\prime}-3^{\prime}\right)$ & Product Size & GenBank Access & Reference \\
\hline MHC-I** & $\begin{array}{l}\text { GGCTACGTGGACGACACG } \\
\text { СССTCCAGGTAGTTCCT }\end{array}$ & 410 & NM_001105651.1 & Birch et al. (2006) \\
\hline MIC-B & $\begin{array}{l}\text { AGAAAGGAGGCTTACATTCCC } \\
\text { GССТGGTAATGСTTGСTTAAC }\end{array}$ & 199 & NM_001127317 & Shu et al. (2012) \\
\hline $\mathrm{NCl}$ & $\begin{array}{l}\text { AGTATTGGGATCAAGAGACGC } \\
\text { ATAGGCGTGСTGATTATACCC }\end{array}$ & 181 & BCl09706 & Shu et al. (2012) \\
\hline NC3 & $\begin{array}{l}\text { AGATGACACGAGATGCCAAG } \\
\text { TCGTTCAGGGCGATGTAA }\end{array}$ & 198 & DQ140378 & Shu et al. (2012) \\
\hline PRM-1 & $\begin{array}{l}\text { AGATACCGATCСTCCTCACС } \\
\text { GCAGСАСАСТСТССТССТС }\end{array}$ & 112 & $\mathrm{BCl} 08207$ & Ferraz et al. (2013) \\
\hline TNP-2 & $\begin{array}{l}\text { GGTCTACGGCAGCACTCACA } \\
\text { TCCTCCTCCTCCTCATCCTT }\end{array}$ & 100 & $\mathrm{BCl09800}$ & Ferraz et al. (2013) \\
\hline LHR & $\begin{array}{l}\text { TCССTGGAGCTGAAGGAAAAT } \\
\text { CGGAAGGGCGTCGTTGTG }\end{array}$ & 199 & NM_174381 & This study \\
\hline 17 $\beta$-HSD3 & $\begin{array}{l}\text { TGGTTCTСAАССTGGСTTССТ } \\
\text { TGССССАССТАTTСТССТАСАС }\end{array}$ & 187 & NM_001076439 & This study \\
\hline GAPDH & $\begin{array}{l}\text { GAGAAGGCTGGGGCTCACTTG } \\
\text { GCTGAСAАTСTTGAGСGTСTTG }\end{array}$ & 195 & NM_001034034.2 & Davies et al. (2006) \\
\hline$\beta$-actin & $\begin{array}{l}\text { GTCCACCTTCCACСAСATGT } \\
\text { GTCACCTTCACCGTTCCAGT }\end{array}$ & 245 & ВТ030480 & Ferraz et al. (2013) \\
\hline
\end{tabular}

*MHC-I (generic) and non-classic MHC class I (MIC-B, NC1 and NC3), Luteinizing Hormone Receptor (LHR), Enzyme 17 $\beta$-Hydroxysteroid Dehydrogenase Type 3 (17 $\beta$-HSD3), Protamine type 1 (PRM-1) and Transition Nuclear Protein type 2 (TNP-2).

**These primers amplify classical MHC-I and the non-classical $N C 1$ genes. 


\section{RESULTS}

\section{Histopathological analysis and bovine testis spermatogenesis assessment}

No macroscopic pathological changes such as ectopic testis, unilateral or bilateral orchitis, testicular torsion, or cryptorchidism were observed. All testes had normal spermatogenesis according to the parameters described by Johnsen (1970), because the seminiferous tubules showed normal tubular diameter and clear lumen. All cell types in most of the tubules, including Sertoli cells, spermatogonia, spermatocytes, and round and elongated spermatids were represented (Figure 1).

The 72 analyzed testes fragments mean Johnsen's scores demonstrated that they belonged to $19.44 \%(14 / 72)$ to score $6,63.89 \%(46 / 72)$ to score 7 , and $16.67 \%(12 / 72)$ to score 8 . There was no statistically significant difference $(\mathrm{p}>0.05)$ between the left and right testes mean scores (mean values of all right and left testes).
Gene expression profile of PRM-1, TNP-2, $17 \beta$-HSD3, LHR, MHC-I (generic), MIC-B, NC1, and NC3 genes in bovine testis

After the spermatogenesis quantitative histopathological analysis, 12 testes fragments of each score $(6,7$, and 8$)$ were randomly selected, in order to perform the described gene expression profile study. GAPDH gene expression was selected as a housekeeping gene to calculate the involved genes relative transcription in bovine spermatogenesis once its $\mathrm{Cq}$ values showed higher stability when compared to $\beta$-actin Cq values in our experiments.

Results showed that all evaluated genes (MHC-I, MICB, NC1, NC3, LHR, 17 $\beta$-HSD3, PRM-1, and TNP-2) were expressed in bovine testis in each studied score, although each gene expression was extremely variable within the same score and only for some genes when compared between scores (Figure 2).

Among the genes analyzed in this study, the MHC-I (generic) gene expression was lower when compared to all genes

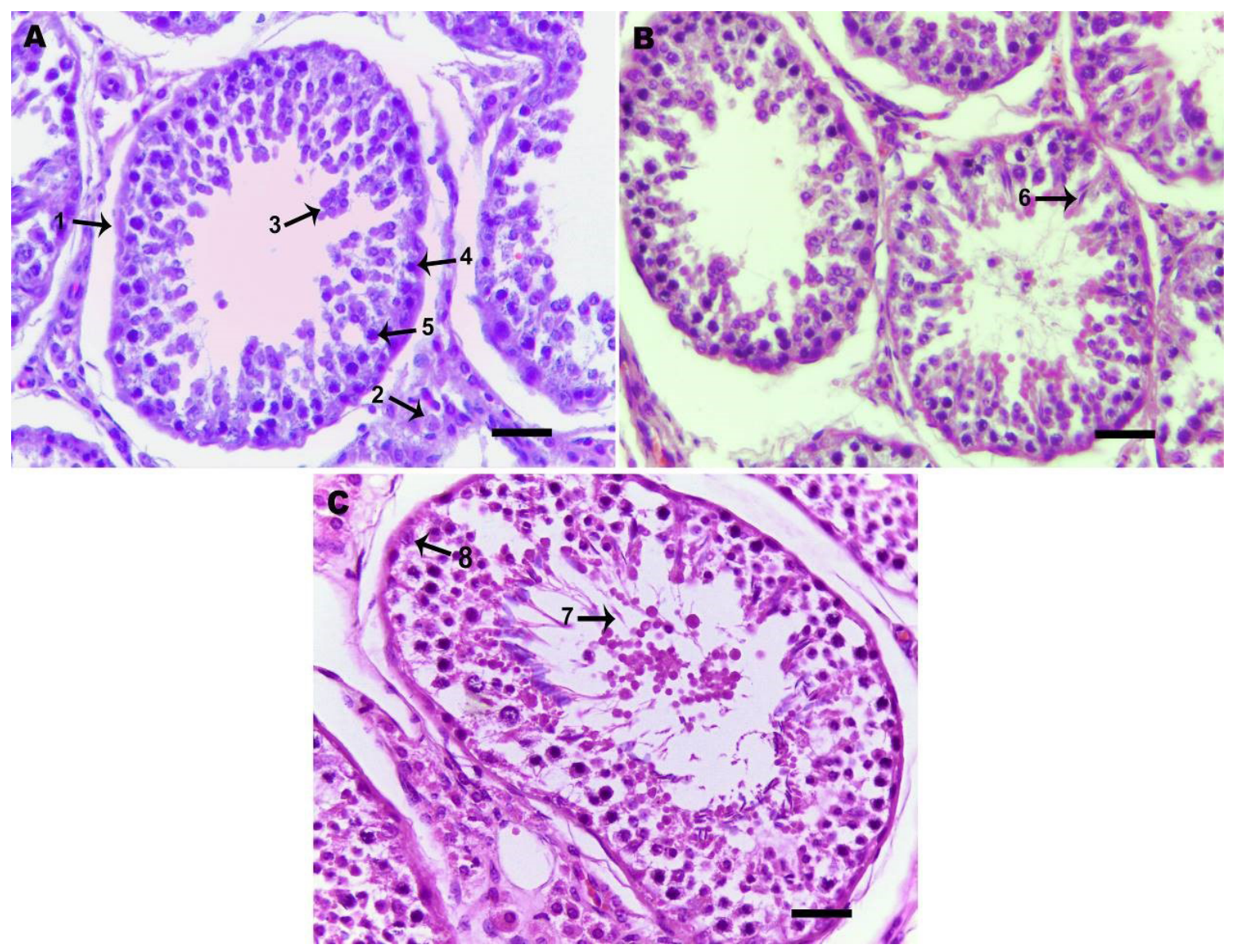

Source: author's collection.

Figure 1. Representative photomicrographs of bovine testis (hematoxylin-eosin-stained), demonstrating normal spermatogenic activity. A. Score 6. Seminiferous tubules (1) and interstitial space containing Leydig cells (2). B. Score 7. Round spermatids (3), spermatogonial cells line (4), primary spermatocytes (5) and elongated spermatids (6). C. Score 8. Spermatozoon (7) and Sertoli cells (8). Scale bar 50 $\mu \mathrm{m}$. Objective 40x. 
in the evaluated scores $(\mathrm{p}<0.05)$. Instead, the PRM-1 and TNP-2 genes were the most expressed among the evaluated genes. The PRM-1 gene expression was significantly higher than TNP-2 gene ( $<$ 0.05). Moreover, for score 6, MICB, $\mathrm{NC1}, \mathrm{NC} 3$, and $17 \beta$-HSD3 genes were less expressed when compared to the LHR gene ( $\mathrm{p}<0.05)$, and, for scores 7 and 8 , $\mathrm{MICB}$ and $\mathrm{NC} 1$ genes were less expressed when compared to NC3, LHR, and 17 $\beta$-HSD3 genes $(p<0.05)$. Comparing the expression profile among the obtained scores, results showed that $17 \beta-H S D 3$ gene expression was lower $(\mathrm{p}<0.05)$ for score 6 when compared to scores 7 and 8 . It was also observed that PRM-1 expression was lower for score 6 when compared to 7 , as well as TNP-2 gene was less expressed for the score 6 (p $<0.05)$ when compared to 7 and 8 scores.

Higher $(r \geq 0.70)$ and significant positive correlation between the gene expression MHC-I (generic) and mean score 6 (Spearman's rank correlation coefficient $r=0.8407 ; \mathrm{p}<0.05$ ) were observed when the gene expression/mean Johnsen's score relation was adopted (Table 2 ). There was significant difference $(\mathrm{p}<0.05)$ in some results when transcriptional genes belonging to the different score groups $(6,7$, or 8$)$ were compared through the Spearman's rank correlation coefficient (Table 3). Average $(0.40<\mathrm{r}<0.70)$ and significant correlation values were recorded between LHR and PRM-1 at mean score 6, as well as between the gene expressions $17 \beta-\mathrm{HSD} 3$ and PRM1. On the other hand, the analyses have shown low $(\mathrm{r} \leq 0.40)$ and significant correlation between the gene expression MIC-B and PRM-1 and TNP-2, respectively, in mean score 7, as well as high $(\mathrm{r} \geq 0.70)$ correlation between the gene expressions PRM- 1 and TNP-2 and genes NC1 and 17 $\beta$-HSD3, respectively (Table 3 ). Finally, the correlation coefficient values in mean score 8 ranged between average $(0.40<\mathrm{r}<0.70)$ and high $(r \geq 0.70)$. There was intermediate correlation between

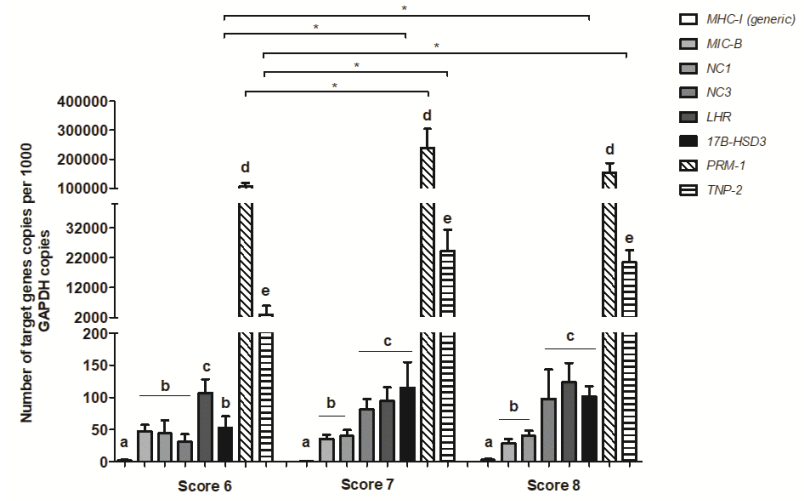

Source: author's collection.

Figure 2. Transcription of MHC-I (generic) and non-classic MHC class I (MIC-B, NCl, and NC3), Luteinizing Hormone Receptor (LHR), Enzyme 17 $\beta$-Hydroxysteroid Dehydrogenase Type 3 (17 $\beta$-HSD3), Protamine type 1 (PRM-l), and Transition Nuclear Protein type 2 (TNP-2) genes in bovine testes. Columns show arithmetic means $(n=36)$ and standard error. Significant statistical differences are indicated by an asterisk $\left({ }^{*}, \mathrm{p}<0.05\right)$. Different letters on the columns indicate statistically significant differences in gene expression evaluated in bovine testes within each score. gene expression PRM-1 and genes NC1 and LHR, respectively, as well as between gene expression TNP-2 and genes MIC-B, LHR and $17 \beta-H S D 3$, respectively. There was high correlation between the gene expression LHR and genes MIC-B and $17 \beta-H S D 3$, respectively; between genes PRM-1 and MIC$\mathrm{B}$; and between gene TNP-2 and genes NC1 and PRM-1, respectively (Table 3 ). No statistically significant correlations ( $p>0.05$ ) were observed between the gene expression NC3 and other genes in all mean scores.

\section{DISCUSSION}

The aim of this study was to correlate the Johnsen's score with differential gene expressions associated with bovine spermatogenesis by using PRM-1, TNP-2, 17 $\beta$-HSD3, and LHR. The generic MHC class I, which amplifies a sequence of MHC-Ia and alleles -Ib belonging to locus $\mathrm{NC1}$, and MHC-Ib (MIC-B, NC1 and NC3) were included in the current research in order to assess their efficiency in the bovine testicular parenchyma during spermatogenesis.

All testes presented normal spermatogenesis, because the seminiferous tubules showed normal tubular diameter and clear lumen (Figure 1). All cell types in most tubules help achieving satisfactory reproductive performance, although the complete fertility determination depends on other variables. Studies showed that the Johnsen's histopathological analysis has been applied to evaluate fertility in men for providing essential prognostic information about abnormal sperm production (RASHED et al., 2007; MAHAJAN et al., 2015).

To our knowledge, the Johnsen score system has never been used in bovine testes. However, this technique has already been applied to evaluate the spermatogenesis in other mammalian species, such as dogs (PETERS et al., 2000), Arabian stallions (LYDKA et al., 2011), Najdi ram lambs (AL-KAWMANI et al.,

Table 2. Correlation between transcription levels of MHC-I (generic) and non-classic MHC class I (MIC-B, NCl and NC3), Luteinizing Hormone Receptor (LHR), Enzyme 17 $\beta$-Hydroxysteroid Dehydrogenase Type 3 (17 $\beta$-HSD3), Protamine type 1 (PRM-l) and Transition Nuclear Protein type 2 (TNP-2) and mean Johnsen's score of bovine testes (r value).

\begin{tabular}{l|c|c|c}
\hline Genes & Score 6 & Score 7 & Score 8 \\
\hline MHC-I & $0.8407^{\star}$ & 0.3162 & -0.1149 \\
\hline MIC-B & 0.0838 & 0.1976 & 0.3001 \\
\hline NCl & 0.5214 & -0.4634 & 0.3715 \\
\hline NC3 & -0.4412 & -0.3274 & 0.4930 \\
\hline LHR & 0.1641 & 0.3341 & 0.5144 \\
\hline l7P-HSD3 & 0.3573 & 0.1473 & 0.3208 \\
\hline PRM-1 & -0.0255 & -0.2622 & 0.4787 \\
\hline TNP-2 & -0.2261 & -0.1652 & 0.4894 \\
\hline
\end{tabular}

${ }^{*}$ ) Spearman's correlation coefficient presenting significant statistical differences $(p<0.05)$. 
Table 3. Correlation between the transcription levels of MHC-I (generic) and non-classic MHC class I (MIC-B, NCl and NC3), Luteinizing Hormone Receptor (LHR), Enzyme 17 $\beta$-Hydroxysteroid Dehydrogenase Type 3 (17 $\beta$-HSD3), Protamine type 1 (PRM-l) and Transition Nuclear Protein type 2 (TNP-2) in mean Johnsen's scores 6, 7 and 8 of bovine testes ( $r$ value).

\begin{tabular}{|c|c|c|c|c|c|c|c|}
\hline \multicolumn{8}{|c|}{ Transcription level of gene expressions in mean score 6 in bovine testes ( $r$ value) } \\
\hline & MIC-B & NC1 & NC3 & LHR & $17 \beta-H S D 3$ & PRM-1 & TNP-2 \\
\hline MHC-I & 0.6000 & 0.4286 & 0.1429 & -0.2571 & 0.3714 & -0.6000 & -0.0286 \\
\hline MIC-B & & 0.3077 & 0.2797 & 0.0979 & -0.1958 & -0.2028 & -0.0489 \\
\hline $\mathrm{NCl}$ & & & -0.0069 & 0.3427 & 0.4965 & 0.2517 & -0.1469 \\
\hline NC3 & & & & -0.3776 & -0.1888 & -0.2657 & 0.4336 \\
\hline LHR & & & & & 0.4825 & $0.5944^{*}$ & -0.1329 \\
\hline $17 \beta-H S D 3$ & & & & & & $0.6643^{*}$ & 0.4476 \\
\hline PRM-1 & & & & & & & 0.2727 \\
\hline \multicolumn{8}{|c|}{ Transcription levels of gene expressions in mean score 7 in bovine testes ( $r$ value) } \\
\hline & MIC-B & NC1 & NC3 & LHR & $17 \beta$-HSD3 & PRM-1 & TNP-2 \\
\hline MHC-I & 0.8000 & -0.6000 & -0.3162 & -0.8000 & -0.8000 & -0.8000 & -0.8000 \\
\hline MIC-B & & -0.4545 & -0.1436 & 0.1608 & -0.3287 & $-0.6014^{*}$ & $-0.7273^{*}$ \\
\hline $\mathrm{NCl}$ & & & 0.3398 & 0.0909 & 0.5524 & $0.8671^{*}$ & $0.7692^{*}$ \\
\hline NC3 & & & & -0.1506 & -0.0980 & -0.0035 & -0.0210 \\
\hline LHR & & & & & 0.4825 & 0.1678 & 0.1119 \\
\hline 17 $\beta$-HSD3 & & & & & & $0.7762^{*}$ & $0.7622^{*}$ \\
\hline PRM-1 & & & & & & & $0.9510^{*}$ \\
\hline \multicolumn{8}{|c|}{ Transcription level of gene expressions in mean score 8 in bovine testes ( $r$ value) } \\
\hline & MIC-B & NC1 & NC3 & LHR & $17 \beta$-HSD3 & PRM-1 & TNP-2 \\
\hline MHC-I & 0.5714 & -0.6667 & -0.1190 & 0.1190 & 0.3832 & 0.3810 & 0.2857 \\
\hline MIC-B & & 0.2727 & 0.1259 & $0.7483^{*}$ & 0.4597 & $0.7273^{*}$ & $0.6503^{*}$ \\
\hline $\mathrm{NCl}$ & & & 0.3636 & 0.3986 & 0.1860 & $0.6993^{*}$ & $0.7203^{*}$ \\
\hline NC3 & & & & 0.3077 & 0.0561 & 0.1888 & 0.2657 \\
\hline LHR & & & & & $0.7860^{\star}$ & $0.6783^{\star}$ & $0.6573^{*}$ \\
\hline 17 $\beta$-HSD3 & & & & & & $0.5333^{*}$ & $0.6105^{*}$ \\
\hline PRM-I & & & & & & & $0.9510^{\star}$ \\
\hline
\end{tabular}

$\left.{ }^{*}\right)$ Spearman's correlation coefficient presenting significant statistical differences $(p<0.05)$.

2014), red deer (PINTUS; ROS-SANTAELLA; GARDE, 2014; PINTUS; ROS-SANTAELLA; GARDE, 2015), and others, as an alternative method for spermatogenesis analysis in such species.

In this study, the classifications were determined following the germinating epithelium maturation level without cellular development clustering stages. Although, there are some spermatogenesis classification systems using the criteria for bovine testes (AMANN, 1962; HORN; MORAES; EDELWEISS, 2003; SILVA et al., 2015), these researchers have found similar results to ours.

In some slides, it was possible to observe exfoliated cells inside the seminiferous tubule's lumen (Figure 1). Cell's exfoliation in lumen may be indicative of testicular degeneration, but it would be possible to observe other degeneration changes such as germ cells vacuolization and multinucleated giant cells formation. In absence of these associated changes, we can consider as artifacts. Moreover, according to Ellenburg et al. (2020), this might be related to specimen size, which could have impacted the fixation quality by the testis tissue. However, all specimens were properly immersed in formalin for approximately 24 hours and using the same processing conditions. Despite histologic artifacts into the seminiferous tubule's lumen, it was possible to evaluate testicular biopsies, which corroborated with our molecular results.

Our results showed that there was no statistically significant difference ( $p>0.05)$ between left and right testicular histopathology in terms of Johnsen score, moreover random effects may affect the Johnsen scoring for bilateral testes, including age, testicular volume, body weight, scrotal circumference and others, but one side could not represent the other (TANG et al., 2018). Therefore, we recommend that both testes biopsy is required depending on the diagnostic test purpose. 
The recorded scores were 6,7 , and 8 , and the proximity among these values may be related to homogeneity within the group of animals (Table 1). Histological findings demonstrated that $83.33 \%$ of testes were belonged to scores 6 and 7 , indicating only presence of spermatids, whereas $16.67 \%$ were in score 8 with only few spermatozoa. These results can be attributed to the animals low genetic merit, which were eliminated from genetic improvement programs and sent to slaughter, as well as the use of young animals that can produce lower values of Johnsen's scoring.

In addition, many factors such as homogeneous animal groups, sexually mature males subjected to the same sanitary control status and different spermatogenesis degrees - from moderate (at scores 6 and 7) to good (score 8), may have influenced the proximity between results.

A study compared the spermatogenesis in the contralateral testis of patients with testicular germ cell cancer, suggested the score condensation in three categories to strengthen the statistical Johnsen's evaluation, representing spermatogenesis "poor" with scores 1 to 3; "moderate", 4 to 7; and "good", 8 to 10 , respectively (DIECKMANN et al., 2007).

Based on these histopathological results, it is possible to state that the Johnsen's criteria are an important instrument to diagnose spermatogenic quality. Therefore, the analyses performed according to such classification allows evaluating the seminiferous tubules in detail, besides morphologically identifying and classifying the cell components in the germinating epithelium, including the maturation interruption precise identification within the germinating cells, as well as possible pathological changes.

Results from qRT-PCR analysis showed that all animals demonstrated normal genes expression, as well as no reproductive abnormalities, higher expression in PRM-1 and TNP-2 genes, being upregulated in crossbred males. These molecules have straight influence on DNA compaction and consequently a proper spermatid differentiation and sperm maturation (FERRAZ et al., 2013). The PRM-1 gene expression was significantly higher than TNP-2 gene $(\mathrm{p}<0.05)$, this result might be associated with the chromatin compaction, mainly in scores 7 and 8 when compared to 6 . It is worth mentioning that in score 6 , a few spermatids are present and the expression in these genes were lower than in scores 7 and 8 . This indicates that the spermatogenesis had already started in the Nelore (Bos taurus indicus) and crossbred bulls of this study, but spermatids are not transformed into spermatozoa yet. Previous studies found out a lower spermatids frequency in poor bulls compared to good bulls suggesting a germ cells partial maturation (TRIPATHI et al., 2014). The greater PMR-1 expressed transcripts showing an adequate germ cells differential development and no deficiency of these. In crossbred males, TNP-2 genes were significantly upregulated showing high condensed sperm nuclei, and low DNA break level, which makes the bovine sperm susceptible to protamination. Recent research results illustrate transition proteins (TNP-1 and TNP-2) upregulation in crossbred (Bos taurus $\mathrm{x}$ Bos indicus) bulls testis might be associated with impaired spermatogenesis processes including improper chromatin compaction (ELANGO et al., 2020).

Therefore, PRM-1 and TNP-2 expressions at Johnsen's spermatogenesis scores found in the present study in the bovine testis would be noticeable, and it would suggest that the sperm chromatin from animals belonging to this species was compact; moreover, it would present relevant parameters to fertility rate predictions. The findings are consistent with those previously in Bos indicus bulls (FORTES et al., 2014; DOGAN et al., 2015). They recorded the association between lower sperm protamine content and sperm DNA instabilities and damages affecting bull fertility. Similar results were also recorded by Ganguly et al. (2013) who found a significant high in mRNAs expression levels of PRM-1 in good quality semen of Frieswal (HF x Sahiwal) crossbred bulls. Evidences link high apoptosis in mature spermatozoa indices to diminished sperm DNA integrity; decreased PRM-1 gene expression has been also described (STEGER et al., 2003; STEGER et al., 2008). Other studies involving humans and horses (SAKKAS et al., 1999; MORRELL et al., 2008; SAKKAS; ALVAREZ, 2010; SCHULTE et al., 2010) reported negative correlation between fertility and sperm DNA fragmentation.

Thus, these findings may suggest that PRM-1 and TNP-2 genes may be functional sperm-quality molecular markers useful to predict infertility acting in final chromatin compaction. It was also observed that PRM-1 expression was lower in score 6 when compared to 7 , as well as TNP-2 gene was less expressed in the score $6(\mathrm{p}<0.05)$ when compared to 7 and 8 scores. The lowest expression of these genes in score 6 is an indication that the Johnsen score shows slight changes in spermatogenesis and the produced spermatozoa in these testis may have changes in sperm chromatin compaction.

There was high and significant correlation $(r \geq 0.70 ; p$ $<0.05$ ) between $17 \beta-$ HSD3 and LHR gene expression and positive correlated with PRM-1 and TNP-2 genes expression belonging to mean score 8 (Table 3). Even though, the testosterone expression observed in our study falls within the observations range as previously reported, only $16.67 \%$ of testes were included in score 8 . This could likely be attributed to variation between bulls or breeds, age groups, season, environmental conditions, and others. Many studies reported that circulating testosterone levels increase with advancing age, but in crossbred bulls the testosterone concentration is significantly lower than Zebu bulls (GULIA et al., 2010; DIAS et al., 2014), indicating that steroidogenesis alteration in those species could be the reason for infertility (ELANGO et al., 2020). Regarding the LHR gene, Coonce et al. (2009) reported 
that it acts in the testicular steroidogenesis and Leydig cells development in mice models. Other authors found that the LHR gene promoter activation happens in spermatogonia and in elongating spermatids (HÄMÄLÄINEN; POUTANEN; HUHTANIEMI, 2001).

Testosterone is the hormone responsible for the secondary sexual characteristics and essential for normal spermatogenesis, consequently an important variable in male fertility studies aiming to help selecting bulls with major reproductive potential (RAJAK et al., 2014; ELANGO et al., 2020). Studies point out that elongated spermatids round maturation during spermiogenesis is testosterone-dependent (O'DONNEL et al., 1994). These results can be associated with most sexually mature bulls; the $17 \beta-H S D 3$ gene seems to play an important role in androstenedione conversion into testosterone, as well as in the spermatogenesis process (O'DONNEL et al., 2001). Similar results have been described (BAKER; SHA; O'SHAUGHNESSY, 1997; O'SHAUGHNESSY et al., 2000) and found that the $17 \beta-\mathrm{HSD}$ type 3 was the major isoform involved in testosterone biosynthesis; it had great expression in the interstitial tissue of mice.

The current research did not record statistically significant difference $(\mathrm{p}>0.05)$ in MHC-Ib (MIC-B, NC1 and NC3) gene expression belonging to obtained scores, thus suggesting that these molecules are poorly expressed in bovine testis (Figure 2). However, significant differences ( $\mathrm{p}<$ 0.05 ) were observed in the generic gene expression MHC-I, which amplifies classical genes MHC-I and NC1 (Figure 2). Such result corroborates the data shown in Table 2, which depicts higher $(r \geq 0.70)$ and significant positive correlation between the generic gene expression MHC-I and mean score 6 , only. It suggests that the MHC-Ia sequence was amplified, because there was no significant difference ( $\mathrm{p} \otimes 0.05$ ) in gene expression $\mathrm{NC} 1$ at the same score. A study found moderate expression of the Mamu-AG molecule - which is homologous to human leukocyte antigen G (HLA-G or MHC-Ib) - in Rhesus Macaque testis (RYAN et al., 2002). However, these results are different from those previously reported (YAO et al., 2014) who found significant increase in the HLA-G mRNA expression in human testicular tissues presenting different spermatogenic abilities, mainly in the late stages, using the Johnsen's score 10.

These findings may suggest that MHC-I have marginal influence on bovine-testis spermatogenesis and that they play a significant role in the physiological processes via immune responses. Authors demonstrate that sperm cells need to keep their integrity during the maturation process to allow their displacement from the basal to the seminiferous tubules adluminal compartment by creating an immunological barrier to protect the autoantigenic germ cells (CURTIS; AMANN, 1981). Further evidences were provided by the study about men's gametogenic cells with azoospermia conducted by
Kurpisz et al. (1987), who investigated the possibility of inducing MHC by viral infections and cytokines that act as adjuvants in immune response activation.

In addition, studies about bovine trophoblastic cells showed non-classical MHC-I proteins as important immunoregulatory factors (DAVIES et al., 2006). Santos et al. (2015) assessed the MIC-B and NC3 genes expression in bovine placental tissues throughout the gestational period and found significantly higher transcription levels in intercotyledonary tissues when they were compared to placentome. Moreover, the MIC-B expression was higher in the second gestational quarter, whereas the NC3 expression was higher in the last two gestational quarters. The same authors also recorded that NC1 and MHC-I (generic) had lower expression in both placental tissues during gestation. Fijak and Meinhardt (2006) mentioned a multitude of necessary factors such as blood-testis barrier and androgens that inhibit proinflammatory cytokine expressions to establish and maintain the immune response in testis. Further studies about reproductive disorders and poor spermatogenesis (scores 1 to 4) in bovine are necessary in order to assess whether the MHC-I (generic) and MHC-Ib genes expression profile, as well as other molecules such as cytokines, which are involved in spermatogenesis regulations, is correlated with pathological disorders. Therefore, the addressed approach provides the foundations to studies focused on analyzing spermatogenesis quality in bovine testis.

\section{CONCLUSIONS}

The MHC I (generic), MIC-B, NC1, NC3, and LHR genes are poorly expressed in the bovine testis, which suggests their marginal action on spermatogenesis. Instead, the PRM-1, TNP2 , and $17 \beta-H S D 3$ genes transcription levels were high in the evaluated scores, supporting the notion that these genes can act directly on the germ cells differential development during bovine spermatogenesis. Since the present study is pioneer in comparing gene expressions (MHC-I generic, MICB, NC1, NC3, LHR and 17 $\beta$-HSD3) belonging to different mean scores in bovine testis, it is worth conducting further research to propose specific spermatogenic-quality markers to predict bovine infertility.

\section{ACKNOWLEDGEMENTS}

We thank the Pathological Anatomy Lab at Universidade Estadual do Maranhão (Brazil), for technical support and equipment involving histopathology. Work in Molecular Pathology Lab was supported by CNPq (Conselho Nacional de Desenvolvimento e Científico e Tecnológico, Brazil), CAPES (Coordenação de Aperfeiçoamento de Pessoal de Nível Superior, Brazil) and FAPEMA (Fundação de Amparo à Pesquisa e Desenvolvimento Científico do Maranhão). Daniele Rosa Xavier had a scolarship from CAPES. 


\section{REFERENCES}

AL-KAWMANI, A. A. et al. Developmental changes in testicular interstitium in the Najdi Ram Lambs. Saudi Journal of Biological Sciences, v. 21, n. 2, p. 133-137, 2014.

AMANN, R. P. Reproductive capacity of daily bulls. III. The effect of ejaculation frequency, unilateral vasectomy and age on spermatogenesis. The American Journal of Anatomy, Baltimore, v. 110, n. 1, p. 49-78, 1962.

ARRUDA, R. P. et al. Morfologia espermática de touros: interpretação e impacto na fertilidade. Revista Brasileira de Reprodução Animal, v. 39, n. 1, p. 47-60, 2015.

BAKER, P. J.; SHA, J. H.; O'SHAUGHNESSY, P. J. Localisation and regulation of $17 \beta$-hydroxysteroid dehydrogenase type 3 mRNA during development in the mouse testis. Molecular and cellular endocrinology, v. 133, п. 2, p. 127-133, 1997.

$\mathrm{BIRCH}$, J. et al. Generation and maintenance of diversity in the cattle MHC class I region. Immunogenetics, v. 58, n. 8, p. 670-679, 2006

CHIANG, M. H. et al. Detection of human leukocyte antigen class I messenger ribonucleic acid transcripts in human spermatozoa via reverse transcription-polymerase chain reaction. Fertility and sterility, v. 61, n. 2, p. 276-280, 1994

COONCE, M. M. et al. Impact of a constitutively active luteinizing hormone receptor on testicular gene expression and postnatal Leydig cell development. Molecular and cellular endocrinology, v. 298, n. 1-2, p. 33-41, 2009.

CURTIS, S. K.; AMANN, R.P.Testicular development and establishment of spermatogenesis in Holstein bulls. Journal of Animal Science, v. 53, n. 6, p. 1645-1657, 1981

DAVIES, C. J. et al. Evidence for expression of both classical and non-classical major histocompatibility complex class I genes in bovine trophoblast cells. American Journal of Reproductive Immunology, v. 55, n. 3, p. 188-200, 2006.

DAVIES, C. J. Why is the fetal allograft not rejected? Journal of animal science, v. 85, n. suppl_13, p. E32-E35, 2007.

DIAS, J. C. et al. Peripheral levels of total testosterone in Guzerat bulls. Ciência Animal Brasileira, v. 15, n. 1, p. 64-73, 2014.

DIECKMANN, K. P. et al. Spermatogenesis in the contralateral testis of patients with testicular germ cell cancer: histological evaluation of testicular biopsies and a comparison with healthy males. BJU international, v. 99, п. 5, p. 1079-1085, 2007.

DOCAN, S. et al. Sperm protamine-status correlates to the fertility of breeding bulls. Biology of reproduction, v. 92, n. 4, p. 1-9, 2015

ELANGO, K. et al. Sub-fertility in crossbred bulls: deciphering testicular level transcriptomic alterations between zebu (Bos indicus) and crossbred (Bos taurus x Bos indicus) bulls. BMC Genomics, v. 21, п. 502, p. 1-14, 2020.

ELLENBURG, J. L. et al. Formalin Versus Bouin Solution for Testis Biopsies: Which Is the Better Fixative? Clinical Pathology, v. 13, p. 1-4, 2020
FERRAZ, M. A. M. M. et al. Gene expression profile of Protamines and Transition Nuclear Proteins in bovine testis. Brazilian Journal of Veterinary Research and Animal Science, v. 50, n. 4, p. 316322, 2013.

FIJAK, M.; MEINHARDT, A. The testis in immune privilege. Immunological reviews, v. 213, n. 1, p. 66-81, 2006.

FORTES, M. R. S et al. Sperm protamine deficiency correlates with sperm DNA damage in Bos indicus bulls. Andrology, v. 2, n. 3, p. 370-378, 2014.

GANGULY, I. et al. Differential expression of protamine $l$ and 2 genes in mature spermatozoa of normal and motility impaired semen producing crossbred Frieswal (HF× Sahiwal) bulls. Research in veterinary science, v. 94, n. 2, p. 256-262, 2013.

GRISWOLD, M. D. Interactions between germ cells and Sertoli cells in the testis. Biology of reproduction, v. 52, n. 2, p. 21l-216, 1995.

GULIA, S. et al. Divergent development of testosterone secretion in male zebu (Bos indicus) and crossbred cattle (Bos indicus $\times$ Bos taurus) and buffaloes (Bubalus bubalis) during growth. Tropical Animal Health and Production, v. 42, p. 1143-1148, 2010.

HÄMÄLÄINEN, T.; POUTANEN, M.; HUHTANIEMI, I. Promoter function of different lengths of the murine luteinizing hormone receptor gene 5 ? -flanking region in transfected gonadal cells and in transgenic mice. Endocrinology, v. 142, n. 6, p. 2427-2434, 2001.

HORN, M. M.; MORAES, J. C. F.; EDELWEISS, M. I. A. Quantificação dos estádios do ciclo espermatogênico em touros de raças sintéticas com e sem alteração na qualidade seminal. Ciência Rural, Santa Maria, v. 33, n. 6, p. 1lll-1l15, 2003.

JOHNSEN, S. G. Testicular biopsy score count-a method for registration of spermatogenesis in human testes: normal values and results in 335 hypogonadal males. Hormone Research in Paediatrics, v. 1, n. 1, p. 2-25, 1970.

JOHNSON, L. et al. Efficiency of spermatogenesis: a comparative approach. Animal Reproduction Science, v. 60-61, p. 471-480, 2000.

KELLEY, J.; WALTER, L.; TROWSDALE, J. Comparative genomics of major histocompatibility complexes. Immunogenetics, v. 56, n. 10, p. 683-695, 2005.

KURPISZ, M. et al. HLA expression on human germinal cells. International Journal of Immunogenetics, v. 14, n. 1, p. 23-32, 1987.

LANGAT, D. K. et al. Differential expression of human leukocyte antigen- $\mathrm{G}(\mathrm{HLA}-\mathrm{G})$ messenger $\mathrm{RNAs}$ and proteins in normal human prostate and prostatic adenocarcinoma. Journal of reproductive immunology, v. 71, n. 1, p. 75-86, 2006.

LARSEN, M. H. et al. Human leukocyte antigen- $\mathrm{G}$ in the male reproductive system and in seminal plasma. Molecular human reproduction, v. 17, n. 12, p. 727-738, 2011.

LYDKA, M. et al. Vimentin expression in testes of Arabian stallions. Equine Veterinary Journal, v. 43, n. 2, p. 184-189, 2011. 
LIVAK, K. J.; SCHMITTGEN, T. D. Analysis of relative gene expression data using real-time quantitative PCR and the $2^{-\Delta \Delta} \mathrm{Ct}$ Method. Methods, v. 25, n. 4, p. 402-408, 2001.

MAHAJAN, A. et al. Histological findings of testicular biopsy in North Indian population. International Journal of Reproduction, Contraception, Obstetrics and Gynecology, v. 4, n. 2, p. 432$438,2015$.

MCLACHLAN, R. I. et al. Histological evaluation of the human testisapproaches to optimizing the clinical value of the assessment: mini review. Human reproduction, v. 22, n. 1, p. 2-16, 2007.

MEISTRICH, M. L. et al. Roles of transition nuclear proteins in spermiogenesis. Chromosoma, v. 1ll, n. 8, p. 483-488, 2003.

MORRELL, J. M. et al. Sperm morphology and chromatin integrity in Swedish warmblood stallions and their relationship to pregnancy rates. Acta Veterinaria Scandinavica, v. 50, n. 1, 2008.

O'DONNELL, L. et al. Testosterone promotes the conversion of round spermatids between stages VII and VIII of the rat spermatogenic cycle. Endocrinology, v. 135, n. 6, p. 2608-2614, 1994.

O'DONNELL, L. et al. Estrogen and spermatogenesis. Endocrine reviews, v. 22, п. 3, p. 289-318, 2001.

O'SHAUGHNESSY, P. J. et al. Localization of $17 \beta$-hydroxysteroid dehydrogenase/17-ketosteroid reductase isoform expression in the developing mouse testis-androstenedione is the major androgen secreted by fetal/neonatal Leydig cells. Endocrinology, v. 14l, n. 7, p. 2631-2637, 2000.

PARHAM, P. MHC class I molecules and KIRs in human history, health and survival. Nature reviews immunology, v. 5, n. 3, p. 201-214, 2005.

PETERS, M. A. J. et al. Spermatogenesis and testicular tumours in ageing dogs. Journal of Reproduction and Fertility, v. 120, n. 2, p. 443-452, 2000.

PINTUS, E.; ROS-SANTAELLA, J. L.; GARDE, J. J. Diagnostic Value of Fine Needle Aspiration Cytology in Testicular Disorders of Red Deer (Cervus elaphus): A Case Report. Journal of Wildlife Diseases, v. 50, n. 4, p. 994-997, 2014.

PINTUS, E.; ROS-SANTAELLA, J. L.; GARDE, J.J. Beyond Testis Size: Links between Spermatogenesis and Sperm Traits in a Seasonal Breeding Mammal. PLoS ONE, v. 10, n. 10, 2015.

RAJAK, S. K. et al. Testicular Cell Indices and Peripheral Blood Testosterone Concentrations in Relation to Age and Semen Quality in Crossbred (Holstein Friesian×Tharparkar) Bulls. Asian-Australasian Journal of Animal Sciences, v. 27, n. 11, p. 1554-1561, 2014.

RASHED, M. et al. Patterns of testicular histopathology in men with primary infertility. The Internet Journal of Urology, v. 5, n. 2, p. 1-9, 2007.

RYAN, A. F. et al. A soluble isoform of the rhesus monkey nonclassical MHC class I molecule Mamu-AG is expressed in the placenta and the testis. The Journal of Immunology, v. 169, ก. 2, p. 673-683, 2002.

SAKKAS, D.; ALVAREZ, J. G. Sperm DNA fragmentation: mechanisms of origin, impact on reproductive outcome, and analysis. Fertility and sterility, v. 93, n. 4, p. 1027-1036, 2010.

SAKKAS, D. et al. Origin of DNA damage in ejaculated human spermatozoa. Reviews of reproduction, v. 4, n. 1, p. 31-37, 1999.

SANTOS, L. S. et al. Transcription of non-classic major histocompatibility complex (MHC) class I in the bovine placenta throughout gestation and after Brucella abortus infection. Veterinary immunology and immunopathology, v. 167, n. 3-4, p. 166-170, 2015.

SCHUUE, R. T. et al. Sperm DNA damage in male infertility: etiologies, assays, and outcomes. Journal of assisted reproduction and genetics, v. 27, n. 1, p. 3-12, 2010.

SHIROISHI, M. et al. Human inhibitory receptors I g-like transcript 2 (ILT2) and IUT4 compete with CD8 for MHC class I binding and bind preferentially to HLA-G. Proceedings of the National Academy of Sciences, v. 100, n. 15, p. 8856-8861, 2003.

SHU, L. et al. Non-classical major histocompatibility complex class makes a crucial contribution to reproduction in the dairy cow. Journal of Reproduction and Development, v. 58, n. 5, p. 569-575, 2012.

SILVA, K. M. et al. Histopathological and histomorphometric testicular characteristics associated to reproductive condition in Bos indicus (Nellore) bulls. Semina: Ciências Agrárias, Londrina, v. 36, n. 3, suplemento l, p. 1935-1944, 2015.

STEGER, K. et al. Decreased protamine-l transcript levels in testes from infertile men. Molecular human reproduction, v. 9, n. 6, p. 331-336, 2003.

STEGER, K. et al. Both protamine-l to protamine-2 mRNA ratio and $\mathrm{Bcl} 2 \mathrm{mRNA}$ content in testicular spermatids and ejaculated spermatozoa discriminate between fertile and infertile men. Human Reproduction, v. 23, n. 1, p. 11-16, 2008.

TANG, W-H. et al. A clinical trial on the consistency of bilateral testicular tissue histopathology and Johnsen score: single side or bilateral side biopsy? Oncotarget, v. 9, п. 35, p. 23848-23859, 2018.

TRIPATHI, U. K. et al. Differential proteomic profile of spermatogenic and Sertoli cells from peri-pubertal testes of three different bovine breeds. Frontiers in Cell and Developmental Biology: Epigenomics and Epigenetics, v. 2, n. 24, 2014.

TROWSDALE, J. Genetic and functional relationships between MHC and NK receptor genes. Immunity, v. 15, n. 3, p. 363-374, 2001.

TUREK, P.J. Practical approaches to the diagnosis and management of male infertility. Nature clinical practice Urology, v. 2, п. 5, p. 226-238, 2005.

YAO, G. D. et al. Expression and potential roles of HLA- $G$ in human spermatogenesis and early embryonic development. PloS one, v. 9, п. 3, 2014. 